\title{
Xancithrix gen.n. (Copepoda: Calanoida), a new benthopelagic genus of Clausocalanoidea from deep Atlantic waters
}

\section{Xancithrix gen.n. (Copepoda: Calanoida), новый бентопелагический род Clausocalanoidea из глубоководной Атлантики}

\author{
Elena L. Markhaseva

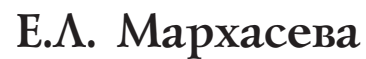

Russian Academy of Sciences, Zoological Institute; Universitetskaya nab. 1, 199034, St. Petersburg, Russia. E-mail: markhaseva@yahoo.com Зоологический институт РАН, Университетская наб. 1, Санкт-Петербург 199034, Россия.

KEY WORDS: Copepoda, Calanoida, new genus, new species, benthopelagic, Atlantic deep sea.

КЛЮЧЕВЫЕ СЛОВА: Сopepoda, Calanoida, новый род, новый вид, бентопелагический, глубоководная Атлантика.

ABSTRACT. A new benthopelagic genus and species Xancithrix ohmani (Clausocalanoidea) with sensory setae on maxilla and maxilliped is described from females and males from the abyss of the South Atlantic. A new genus is proposed as it is amongst the most primitive bradfordian genera retaining the ancestral bradfordian setal pattern of mouth parts: the maxilliped praecoxal endites of the syncoxa have a setal sequence of $1,2,3$; the maxilla praecoxal endite and endopod with 5 and 9 setae respectively, and the maxillule praecoxal arthrite, coxal endite, proximal and distal basal endites, endopod, exopod and coxal epipodite has a setal sequence of $14,5,4,5,11,10$, and 9 , respectively. This new genus is attributed to the Diaixidae and is distinct from all other diaixids in not having a rostrum, the maxilliped coxal endite with a small distal attenuation, and the P1 endopod lateral lobe bears a pore.

РЕЗЮМЕ. Новый бентопелагический род и вид Xancithrix ohmani из «брэдфордовской» группы семейств Clausocalanoidea c сенсорными щетинками на максилле и максиллипеде из абиссали южной Атлантики описан по самкам и самцам. Полагается, что новый род принадлежит к примитивным представителям брэдфордовской группы родов, так как он сохраняет анцестральный для этой группы тип вооружения ротовых частей: последовательность щетинок на прекоксальных эндитах синкоксы максиллипеды $1,2,3$; прекоксальный эндит максиллы и ее эндоподит с 5 и 9 щетинками, соответственно; последовательность щетинок $14,5,4,5$, 11,10, и 9 , соответственно, на прекоксальном артрите, коксальном, базальных проксимальном и дистальном эндитах, эндоподите, экзоподите и коксальном эпиподите. Новый род отнесен к Diaixidae, он хорошо отличим от остальных диаиксид по следующим признакам: у самок рострума нет; кок- сальный эндит синкоксы максиллипеды с маленьким выступом на дистальном крае, латеральная лопасть эндоподита P1 несет пору.

\section{Introduction}

Recent studies of the poorly known benthopelagic copepods of the World Ocean show that their fauna is highly diverse and includes many new species and genera [e.g., Bradford-Grieve, 2001; Markhaseva \& Ferrari, 2005; Ohtsuka et al., 2003; Schulz, 2006]. Every collection from deep waters taken in the vicinity of the sea bed contributes new data on the biodiversity of this biotope. A new bradfordian calanoid genus and species Xancithrix ohmani is described below. This species was obtained from the abyssal near-bottom environment of the South Atlantic and supplements the list of bradfordian benthopelagic calanoids. Calanoid families of clausocalanoideans possessing sensory setae on the maxilla and, usually, the maxilliped (Diaixidae, Tharybidae, Scolecitrichidae, Parkiidae, Kyphocalanidae, Rostrocalanidae and Phaennidae) are named "bradfordian" [Ferrari \& Steinberg, 1993; Ferrari \& Markhaseva, 1996] honoring Janet Bradford-Grieve, who was among the first to describe in details the different kinds of the sensory setae. Members of the Diaixidae and Tharybidae belong to the ancestral group of bradfordians which retain $1,2,3$ setae on the proximal, middle and distal praecoxal lobes of the maxilliped syncoxa [Markhaseva \& Ferrari, 2005].

Both sexes of a new genus and species Xancithrix ohmani are described here and placed in the Diaixidae sensu Markhaseva \& Ferrari [2005]. Taking into consideration several bradfordians of the ancestral group described since 2005 [Markhaseva \& Schulz, 2006, 2010; Schulz, 2006] I now include in the family the following genera: Diaixis Sars, 1902, Neoscolecithrix Canu, 1896, Xantharus Andronov, 1981, Landrumius 
Park, 1983, Falsilandrumius Vyshkvartzeva, 2001, Cenognatha Bradford-Grieve, 2001, Byrathis Markhaseva et Ferrari, 2005, Sensiava Markhaseva et Schulz, 2006, Paraxantharus Schulz, 2006, Procenognatha Markhaseva et Schulz, 2010, Ranthaxus Markhaseva et Schulz, 2010, and, probably, Grievella Ferrari et Markhaseva, 2000. Grievella was previously considered to be a tharybid [Markhaseva \& Ferrari, 2005], however, precise differentiation between diaixids and tharybids is uncertain until both sexes of all genera in these families have been described. Thus the current assignment of some genera in the Diaixidae or Tharybidae is tentative.

\section{Material and methods}

Benthopelagic calanoid copepods were collected by RV Meteor during DIVA I-II expeditions in the years 2005 and 2009 in the vicinity of the sea bed in the abyss of the South Atlantic between equator and $28^{\circ} \mathrm{S}$ at depths of 4482 to $5184 \mathrm{~m}$ using an epibenthic sledge [Brenke, 2005].

Specimens were stained by adding a solution of chlorazol black E dissolved in $70 \%$ ethanol $/ 30 \%$ water. Oral parts and swimming legs were dissected, mounted in glycerin and figured using a camera lucida.

The following abbreviations are used in the descriptions: P1-P4, swimming legs 1-4. Free segments of the antennule are designated by Arabic numerals, ancestral segments by Roman numerals. One seta and one aesthetask on a segment of the antennule are designated: $1 \mathrm{~s}+1 \mathrm{ae}$, " 1 ?" indicates that a setal element was broken so that its identity on the antennule could not be determined and only the scar at the location of its attachment was counted.

Further, the segmentation of the maxilla follows Ferrari and Ivanenko [2008] (earlier terms are given in parenthesis for easier understanding) and the syncoxa of the maxilliped is considered to have three praecoxal endites and one coxal endite fused together in a syncoxa [Ferrari \& Markhaseva, 2000a,b; Ferrari \& Ivanenko, 2001].

The type specimens are deposited at the Zoological Museum Hamburg (ZMH), University of Hamburg and the Zoological Institute of the Russian Academy of Sciences (ZIN).

\section{Taxonomy}

Family Diaixidae Sars, 1902

\section{Genus Xancithrix gen.n.}

Type species Xancithrix ohmani sp.n., here designated.

DIAGNOSIS. Female. Diaixidae. Cephalosome and pediger 1, pedigers 4 and 5 partly fused. Posterior corners of prosome as short obtuse-triangular lobes. Rostrum absent. Antennule of 24 free segments. Coxa of antenna with 1 seta, basis with 2 setae; endopod segment 1 with 2 setae; antenna exopod proximal segments 1 and 2 without setae. Mandibular gnathobase cutting edge with 10 teeth; endopod segments 1 and 2 with 2 and 9 setae respectively. Maxillule praecoxal arthrite with 14 setal elements; coxal endite with 5 setae, proximal basal endite with 4 setae; distal basal endite with 5 setae, endopod with 11 setae, exopod with 10 setae; coxal epipodite with 9 setae. Maxilla praecoxal endite bearing 5 setae, proximal basal endite with 2 sclerotized plus 1 sensory setae; lobe of proximal endopodal segment with 2 sclerotized plus 2 sensory setae; endopod with 3 worm-like, 5 brush-like and 1 sclerotized setae. Maxilliped syncoxa with 1, 2, and 3 setae on praecoxal endites; coxal endite with 3 setae, small attenuation and spinules along distal edge. Segmentation and setation of P1-P4 typical for Clausocalanoidea. P5 uniramous, 3-segmented; exopod segment 3 with 3 terminal spines.

Male. Cephalosome and pediger 1 nearly completely fused, pedigers 4 and 5 completely fused. Posterior corners of prosome in form of short obtuse lobes. Rostrum rudimentary with small terminal notch. Right antennule of 23, left of 24 free segments. Oral parts rudimentary compared to female. Lateral spines of P1 exopod segments 1 to 3 and P2-P4 exopod segment 1 shorter than in female. P5 biramous, endopods rudimentrary; right protopod shorter than left; exopods 3-segmented.

REMARKS. Xancithrix gen.n. is considered to be one of the most primitive genera among the bradfordian families and retains the following ancestral bradfordian setal pattern of oral parts: 1) a setal sequence of 1, 2, 3 on the praecoxal endites of the maxilliped syncoxa (shared with the Tharybidae and Diaixidae); 2) the maxilla praecoxal endite and endopod with 5 and 9 setae respectively (shared with diaixid genera Procenognatha, Xantharus, Landrumius, Falsilandrumius, Neoscolecithrix, Paraxantharus and Grievella, and some phaennids of Xanthocalanus Giesbrecht, 1892 and Brachycalanus Farran, 1905), and 3) a setal sequence of $14,5,4,5,11,10$, and 9, respectively, on the maxillule praecoxal arthrite, coxal endite, proximal basal endite, distal basal endite, endopod, exopod and coxal epipodite (shared with some phaennid species of Xanthocalanus).

The new genus belongs to the lineage containing ancestral bradfordian families Diaixidae and Tharybidae. It is closer to the Diaixidae in having more than 6 setae on the maxillule exopod (vs 2-6 setae in tharybids) and in the trapezoidal shape of the maxillule praecoxal arthrite not vaulted (vs vaulted in Tharybis).

Xancithrix gen.n. is distinguished from the other members of Diaixidae by the following combination of derived characters: rostrum absent in females, maxilliped syncoxa with small distal attenuation on the coxal endite and P1 endopod bearing lateral lobe with pore.

ETYMOLOGY. The generic name is a combination of Xanthocalanus and Neoscolecithrix and refers to the similarity of some morphological characters of the new genus with regard to these genera. Gender masculine. 


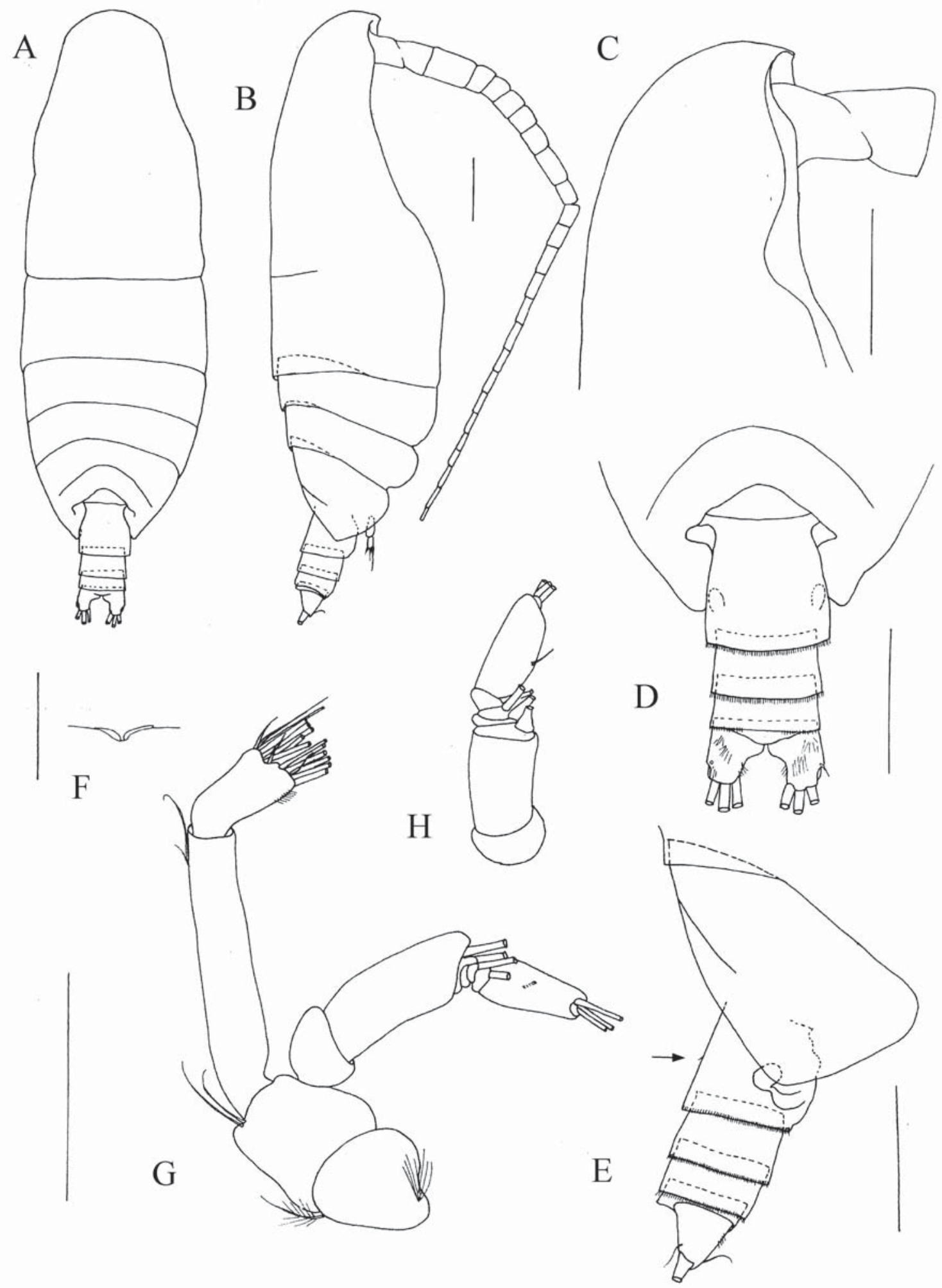

Fig. 1. Xancithrix ohmani gen. et sp.n. Female: A — habitus, dorsal view; B - habitus, lateral view; C - cephalon, lateral view; D posterior prosome and urosome, dorsal view; $\mathrm{E}$ - prosome and urosome, lateral view (dorsolateral seta marked by arrow); $\mathrm{F}$ - cephalon, anterior ventral view; G - antenna; H - antenna, exopod. A, D, F, holotype. B, C, E, G, H, paratype. Scales bars for A-B - $0.5 \mathrm{~mm}$, remaining figures $-0.1 \mathrm{~mm}$.

Рис. 1. Xancithrix ohmani gen. et sp.n. Самка: A - общий вид со спины; В - общий вид сбоку; C - цефалон, вид сбоку; D задняя часть просомы и уросома, вид со спины; Е - задняя часть просомы и уросома, вид сбоку (стрелка указывает на дорсолатеральную щетинку); $\mathrm{F}$ - цефалон, передняя часть, вид с брюшной стороны; $\mathrm{G}$ - антенна; $\mathrm{H}$ - антенна, экзоподит. А, D, F - голотип. B, C, E, G, H - паратип. Масштаб для A-B - 0,5 мм, для остальных рисунков - 0,1 мм. 


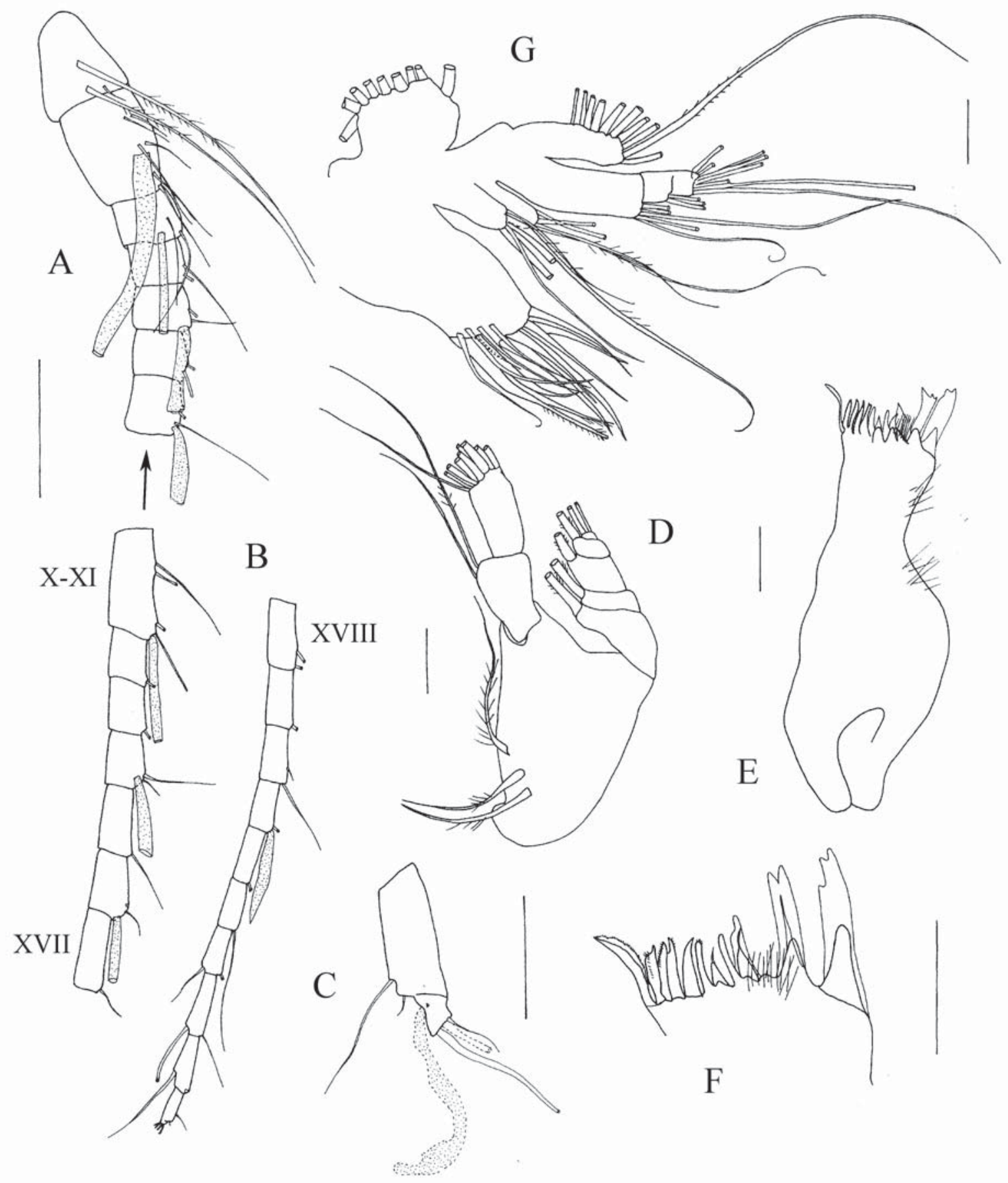

Fig. 2. Xancithrix ohmani gen. et sp.n. Female, holotype: A - antennule, ancestral segments I-XVII; B - antennule, ancestral segments XVIII- XXVIII; C — antennule, ancestral segments XXVII-XXVIII (dotted line marks additions after paratype); D - mandible, palp; E - mandible, gnathobase; F — mandible, cutting edge, gnathobase; G - maxillulle. Scale bars $0.1 \mathrm{~mm}$.

Pис. 2. Xancithrix ohmani gen. et sp.n. Самка, голотип: А - антеннула, анцестральные сегменты I-XVII; B — антеннула, анцестральные сегменты XVIII- XXVIII; C - антеннула, анцестральные сегменты XXVII-XXVIII (пунктиром дополнения по паратипу); D — мандибула, щупик; Е — мандибула, гнатобаза; F — мандибула, жевательный край гнатобазы; G — максиллула. Масштаб 0,1 мм. 


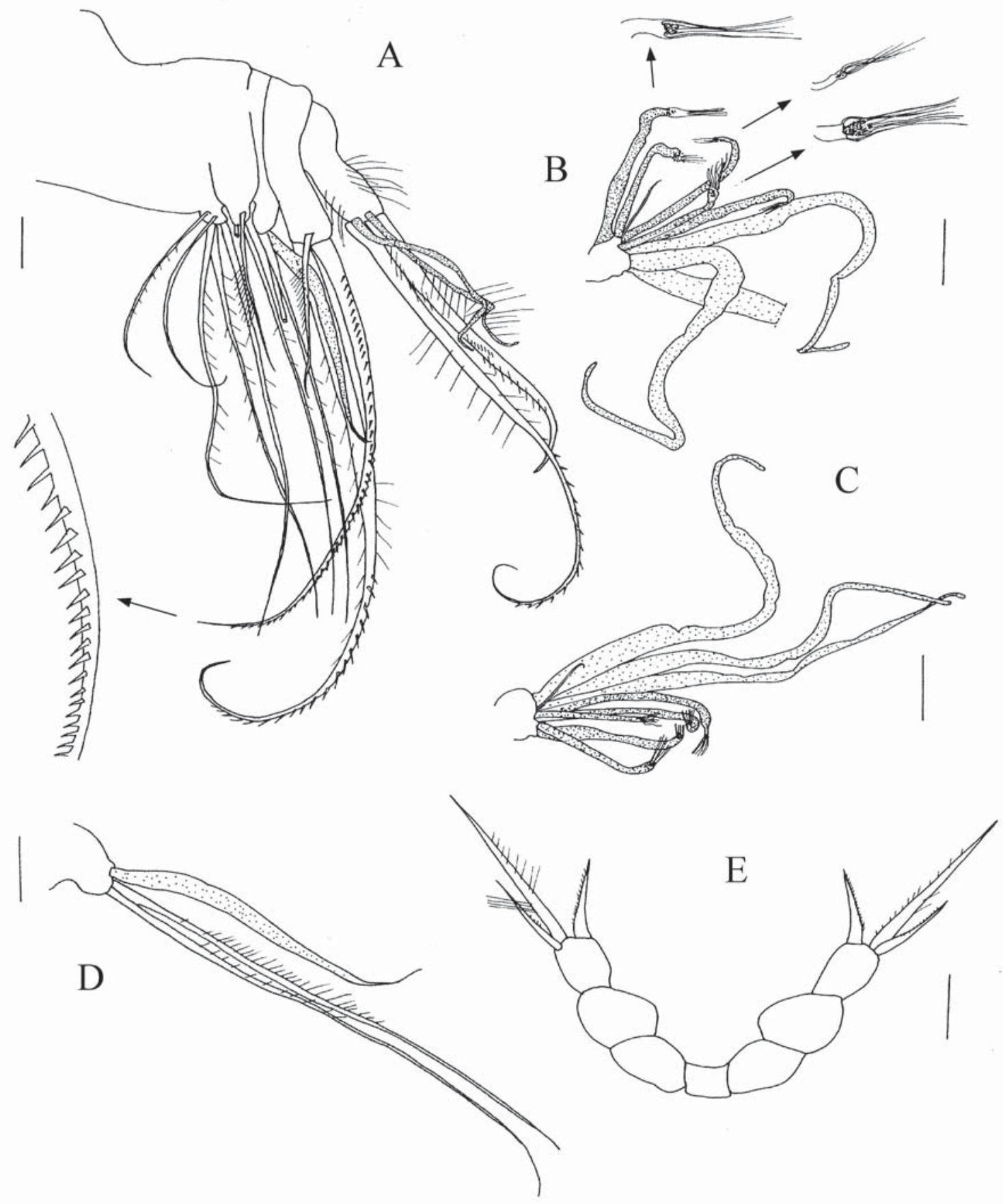

Fig. 3. Xancithrix ohmani gen. et sp.n. Female: A - maxilla, praecoxal, coxal, and basal endites, proximal endopodal segment; B maxilla, endopod; C - maxilla, endopod; D - maxilla, proximal basal endite; E - P5. A-B, D, E - holotype. C - paratype. Scale bars $0.1 \mathrm{~mm}$.

Рис. 3. Xancithrix ohmani gen. et sp.n. Самка: A — максилла, прекоксальный, коксальные и базальный эндиты, проксимальный сегмент эндоподита; В - максилла, эндоподит; C — максилла, эндоподит; D - максилла, проксимальный базальный эндит; Е P5. A-B, D, E - голотип. C - паратип. Масштаб 0,1 мм. 


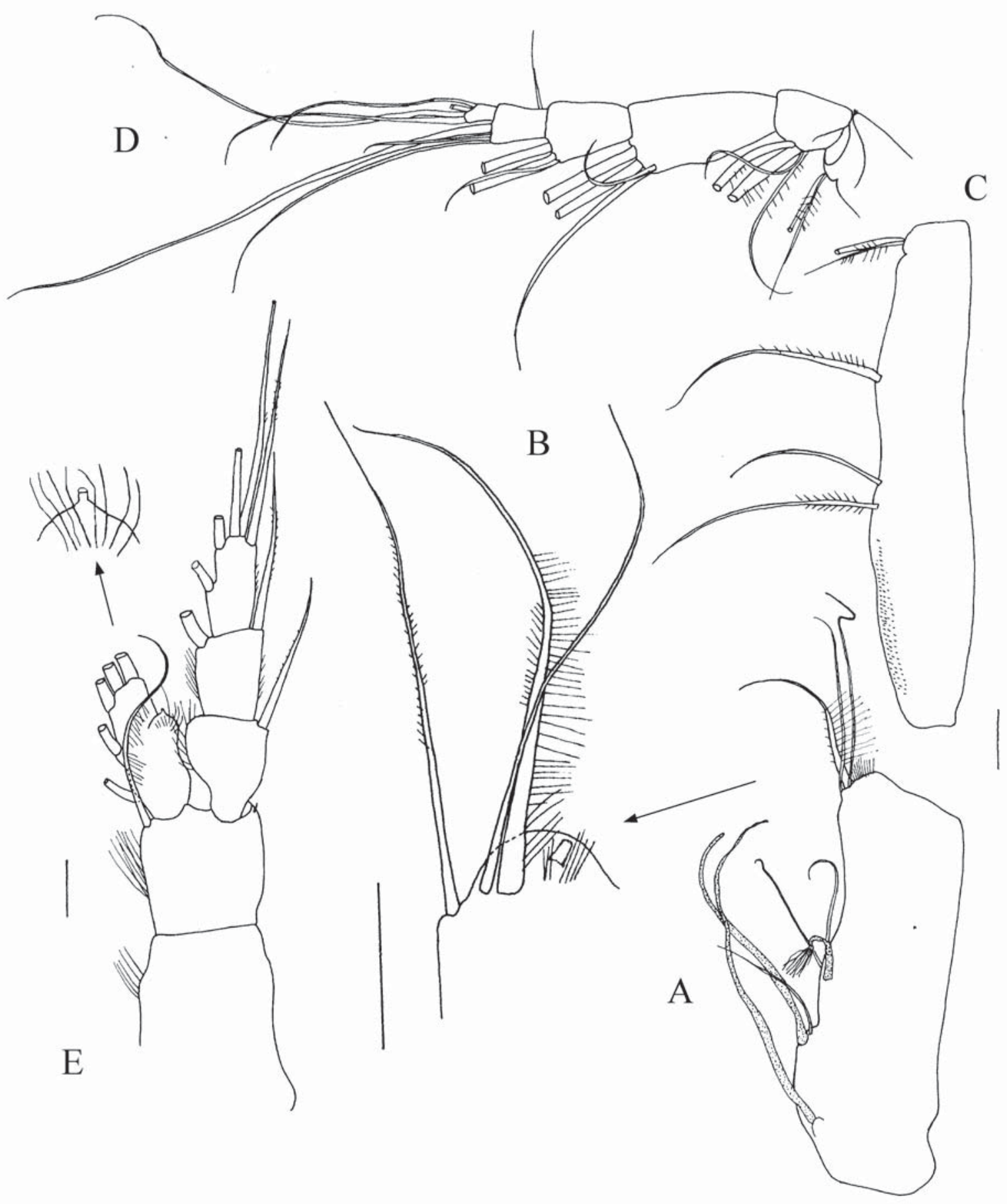

Fig. 4. Xancithrix ohmani gen. et sp.n. Female, holotype: A — maxilliped, syncoxa; B — maxilliped, syncoxa, coxal endite; C — maxilliped, basis and incorporated endopod segment 1; D - maxilliped, endopod; E - P1. Scale bars $0.1 \mathrm{~mm}$.

Рис. 4. Xancithrix ohmani gen. et sp.n. Самка, голотип: А - максиллипеда, синкокса; В - максиллипеда, синкокса, коксальный эндит; C — максиллипеда, базис с включенным в него первым сегментом эндоподита; D — максиллипеда, эндоподит; Е P1. Масштаб 0,1 мм. 

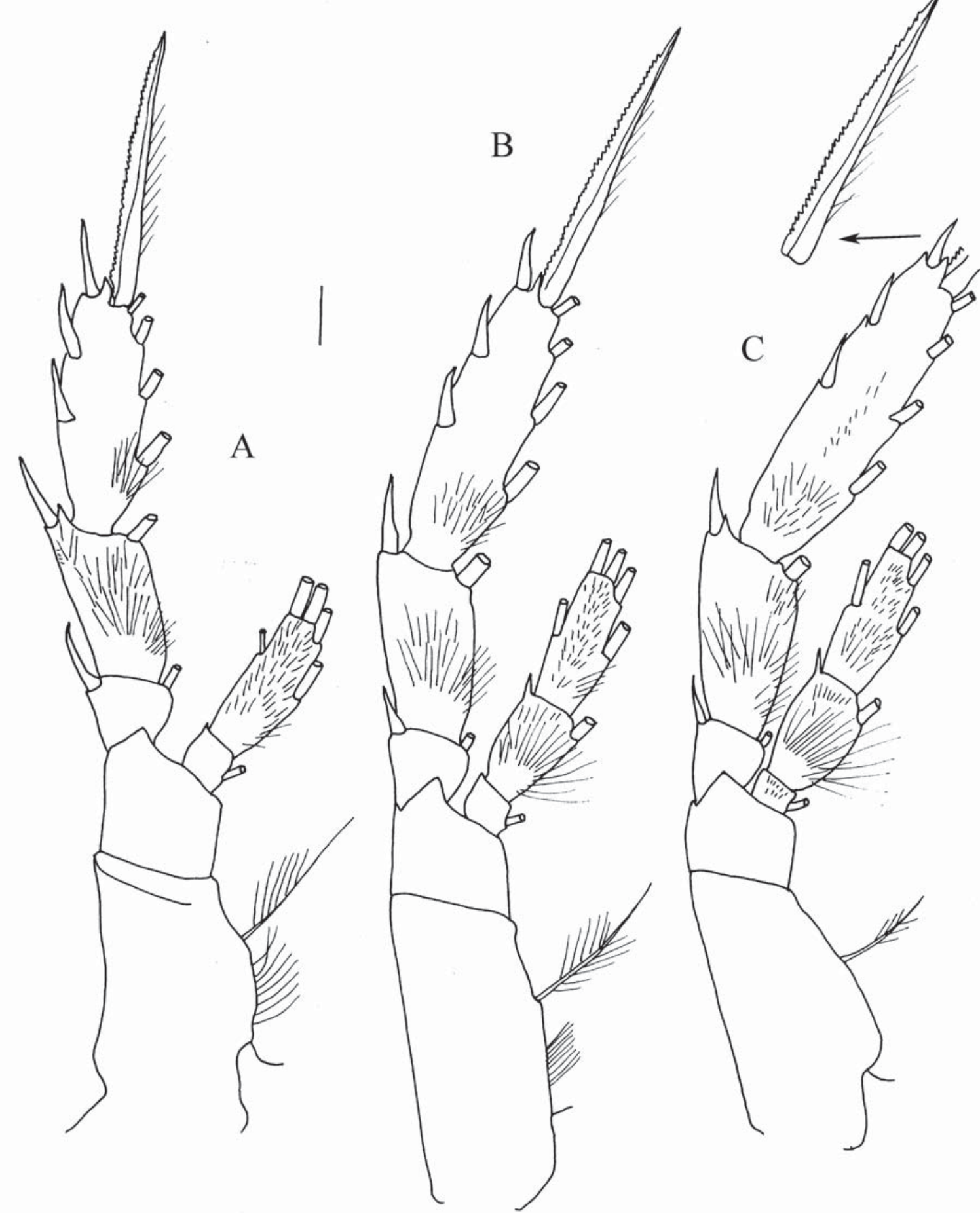

Fig. 5. Xancithrix ohmani gen. et sp.n. Female, holotype: A - P2, posterior; B - P3, posterior; C - P4, posterior. Scale bar $0.1 \mathrm{~mm}$. Рис. 5. Xancithrix ohmani gen. et sp.n. Самка, голотип: А - Р2, вид сзади; В - Р3, вид сзади; С - Р4, вид сзади. Масштаб 0,1 MM. 


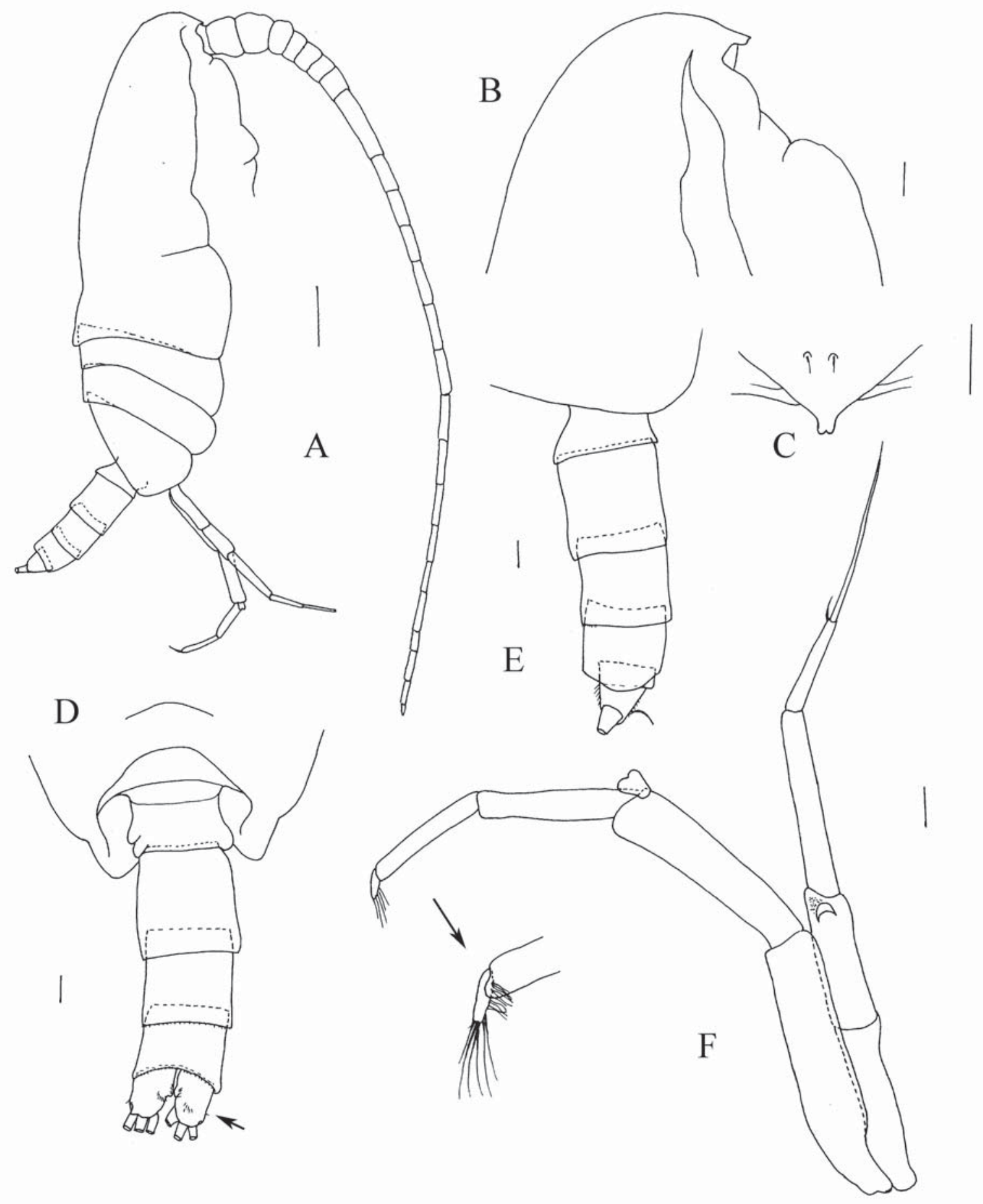

Fig. 6. Xancithrix ohmani gen. et sp.n. Male, paratype: A - habitus, lateral view; B - cephalon, lateral view; C - rostrum, ventral view; D - posterior prosome and urosome, dorsal view; E - prosome and urosome, lateral view; F - P5. Scales bars for A-B - $0.5 \mathrm{~mm}$, remaining figures $-0.1 \mathrm{~mm}$.

Pис. 6. Xancithrix ohmani gen. et sp.n. Самец, паратип: А - общий вид сбоку; В - цефалон, вид сбоку; С - рострум, вид с брюшной поврехности; D - задняя часть просомы и уросома, вид со спины; $\mathrm{E}$ - просома и уросома, вид сбоку; F — P5. Масштаб для $\mathrm{A}-\mathrm{B}-0,5$ мм, для остальных рисунков - 0,1 мм. 


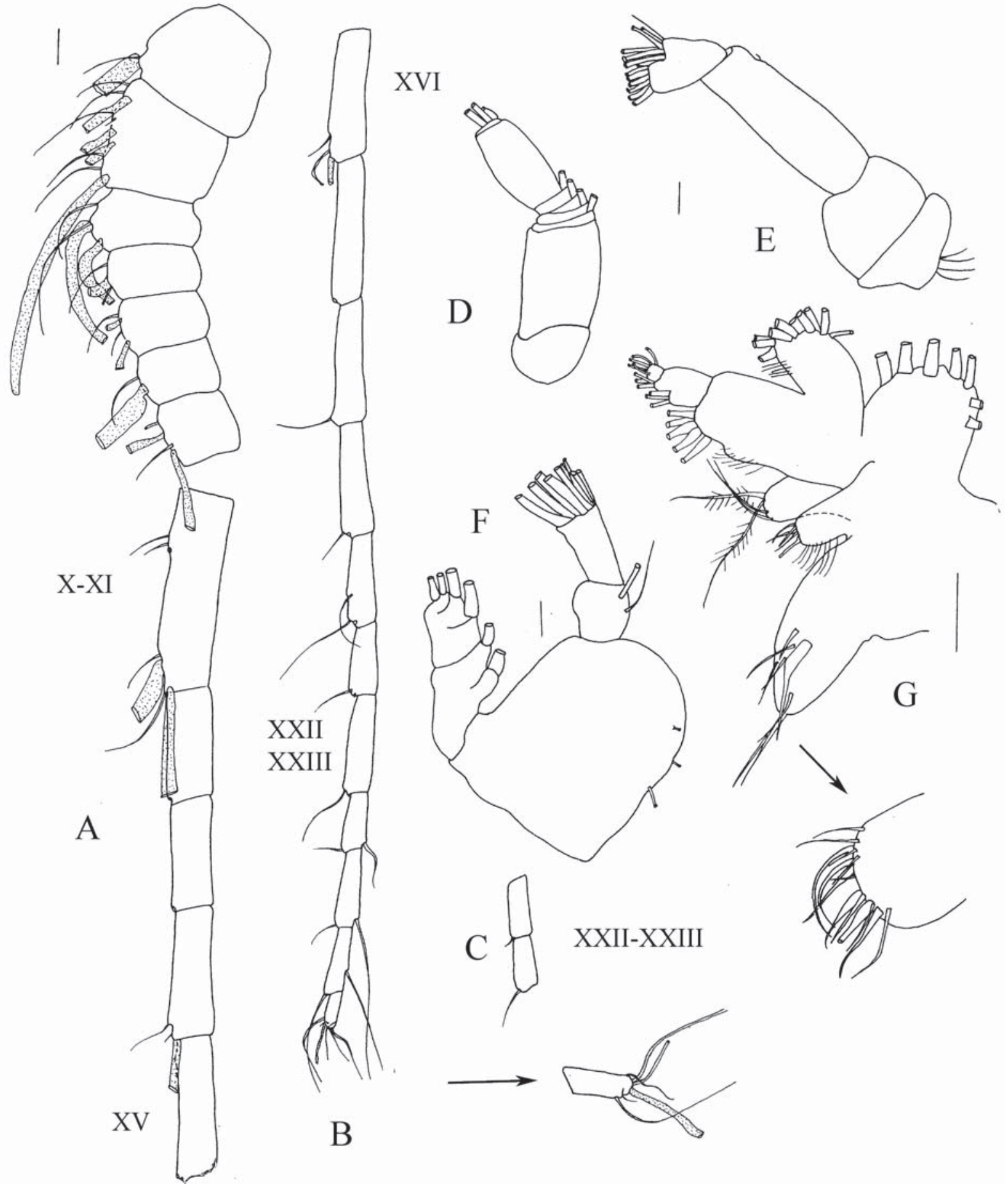

Fig. 7. Xancithrix ohmani gen. et sp.n. Male, paratype: A — right antennule, ancestral segments I-XV; B — right antennule, ancestral segments XVI-XXVIII; C — left antennule, ancestral segments XXII-XXIII; D — antenna exopod; E - antenna, coxa, basis and endopod; F - mandible, palp; G - maxillulle. Scale bars $0.1 \mathrm{~mm}$.

Рис. 7. Xancithrix ohmani gen. et sp.n. Самец, паратип: А - правая антеннула, анцестральные сегменты I-XV; B - правая антеннула, анцестральные сегменты XVI - XXVIII; C - левая антеннула, анцестральные сегменты XXII-XXIII; D - антенна, экзоподит; Е - антенна, кокса, базис и эндоподит; F — мандибула, щупик; G — максиллула. Масштаб 0,1 мм. 


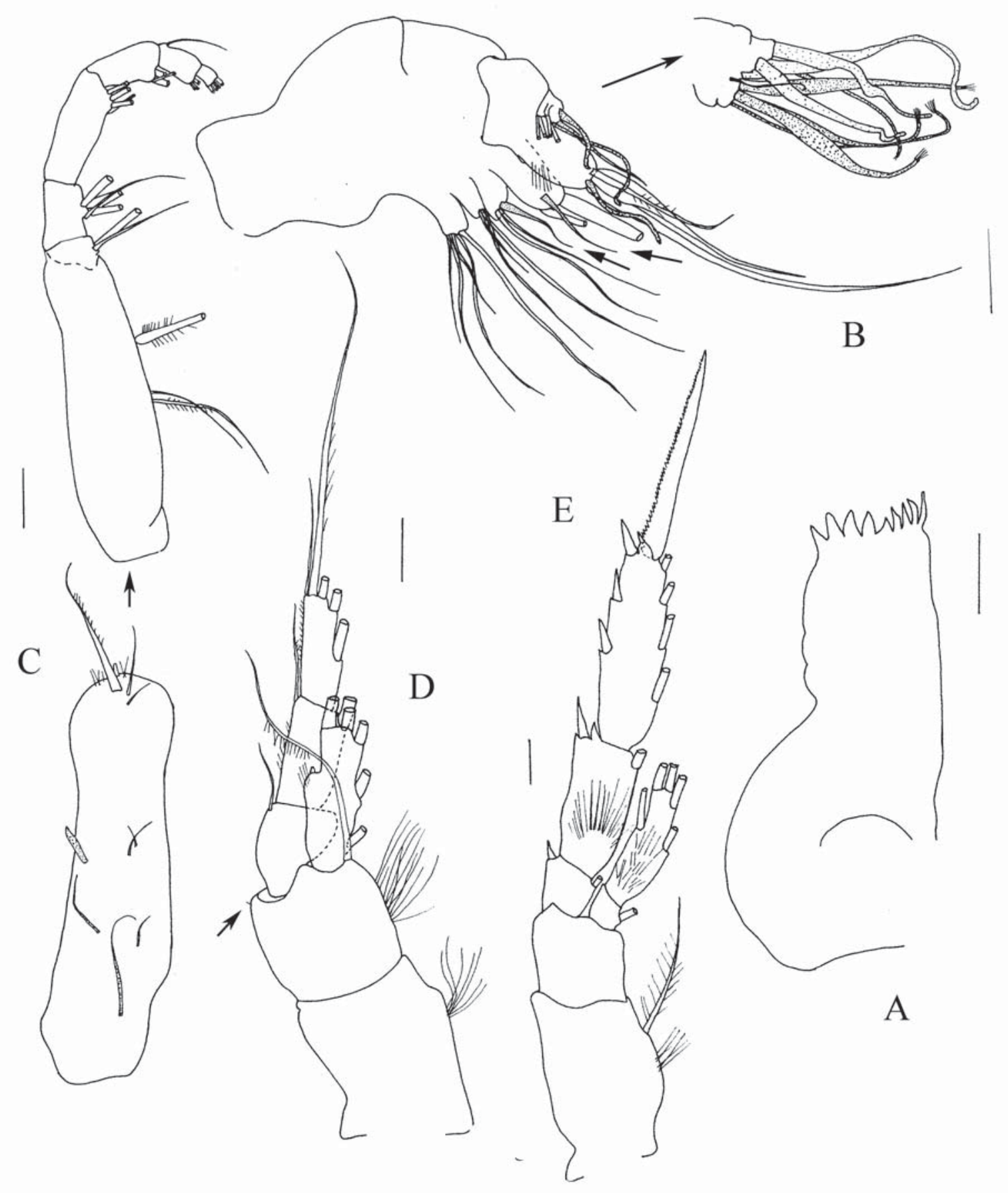

Fig. 8. Xancithrix ohmani gen. et sp.n. Male, paratype: A — mandible, gnathobase; B — maxilla (arrow marks sensory setae on basal endites); C - maxilliped; D - P1 (arrow marks small lateral seta), E - P2. Scale bars $0.1 \mathrm{~mm}$

Рис. 8. Xancithrix ohmani gen. et sp.n. Самец, паратип: A - мандибула, гнатобаза; В - максилла (стрелка показывает на сенсорные щетинки базальных эндитов); C — максиллипеда; D — P1 (стрелка указывает на маленькую латеральную щетнку); Е — P2. Масштаб 0,1 мм. 


\section{Xancithrix ohmani sp.n.}

Figs 1-7.

MATERIAL. Holotype, adult female, dissected, body length $4.5 \mathrm{~mm}$ (ZMH K-42423), Atlantic Ocean, 2801,9'S 07 $18,6^{\prime} \mathrm{E}$ DIVA II expedition, station 41, 04 March 2005, above the seabed at a depth of $5053 \mathrm{~m}$. Paratypes, adult male, dissected, body length $4.6 \mathrm{~mm}$ (ZMH K-42424), same lable data as for holotype; 1 female, body length $4.55 \mathrm{~mm}$ (ZIN 91107), Atlantic Ocean, 00 45,3'S $05^{\circ} 35,0^{\prime} \mathrm{W}$, DIVA II expedition, station 89, 20 March 2005, above the seabed at a depth of $5141 \mathrm{~m} ; 2$ females, body length $4.55 \mathrm{~mm}$ (ZIN 91108), Atlantic Ocean, $00^{\circ} 01,2^{\prime} \mathrm{S} 02^{\circ} 28,7^{\prime} \mathrm{W}$, DIVA II expedition, station 63, 15 March 2005, above the seabed at a depth of $5058 \mathrm{~m}$.

DESCRIPTION. Adult female, total length 4.50$4.55 \mathrm{~mm}$; prosome 4.6-5.0 times longer than urosome. Cephalosome and pediger 1 and pedigers 4 and 5 partly fused; posterior corners of prosome extends as short obtuse-triangular lobes (Fig. 1A-B, D-E). Genital double-somite with spermathecae rounded dorsally (Fig. 1E). Rostrum reduced (Fig. 1C, F). Caudal rami with 4 terminal plus 1 ventral and 1 dorsolateral setae (Fig.1D-E).

Antennules (Fig. 2A-C) reaching to the of middle of urosome; of 24 free segments, armature as follows: I-3s, II-IV-6s + 1ae, V-2s + 1ae, VI-2s, VII-2s + 1ae, VIII-2s, IX-2s + 1ae, X-XI-4s + 1ae, XII-1s, XIII-1s, XIV-2s + 1ae, XV-1s, XVI-2s + 1ae, XVII$1 \mathrm{~s}$, XVIII-2s, XIX-1s, XX-2s, XXI-1s + 1ae, XXII to XXIII-1s each, XXIV to XXVI-2s each, XXVIIXXVIII-5s + 1ae.

Antenna (Fig. 1G-H), coxa with 1 seta, basis with 2 setae, exopod 8-segmented with $0,(0-0-0), 1,1,1,1$, 1 and 3 setae; exopod nearly 0.9 times as long as endopod; first endopodal segment with 2 setae, second with 9 and 7 setae.

Mandible (Fig. 2D-F), gnathobase with 10 teeth and thick dorsal seta; basis with 3 setae, exopod 5segmented, with 1, 1, 1, 1, and 2 setae; endopod segment 1 with 2 setae, segment 2 with 9 setae.

Maxillule (Fig. 2G), praecoxal arthrite with 9 terminal, 4 posterior and 1 anterior setae; coxal endite with 5 setae, proximal basal endite with 4 setae and distal basal endite with 5 setae; endopod of 3 segments with 3, 3, and 5 setae; exopod with 10 setae; coxal epipodite with 9 setae.

Maxilla (Fig. 3A-D), praecoxal endite bearing 5 setae, coxal (former considered distal praecoxal endite) with 3 setae; basal endites (former considered coxal endites): proximal with 2 sclerotized and 1 sensory setae, distal with 3 setae, 2 of them heavily spinulated; lobe of proximal endopodal segment (former considered proximal basal endite) with 2 sclerotized and 2 sensory setae; endopod with 3 long worm-like sensory, 5 brushlike sensory and 1 sclerotized setae.

Maxilliped (Fig. 4A-D), proximal praecoxal endite with 1 worm-like sensory seta, 1 sclerotized and 1 sensory setae on middle endite and 1 worm-like, 1 brush-like and 1 sclerotized seta on distal praecoxal endite; coxal endite of syncoxa with 3 setae, small attenuation and spinules along distal edge; basis with 3 medial setae. Endopod with 2, 4, 4, 3, 3+1, and 4 setae.

P1 (Fig. 4E), coxa without seta; basis with very small distolateral seta, medial distal seta curved; endopod 1-segmented bearing lateral lobe with pore and ornamented with spinules. Exopod segments 1, 2, and 3 with 1 lateral spine each; spine of exopod segment 1 reaching to mid-length of exopod segment 3 , spine of exopod segment 2 reaching nearly to mid-length of the second spine.

P2 (Fig. 5A), coxa with medial seta; basis without seta; endopod 2-segmented; exopod 3-segmented; posterior surface of endopod segment 2 and exopod segments 2 and 3 spinulated. Spine of exopod segment 1 curved.

P3 (Fig. 5B), coxa with medial seta, basis without seta; both endopod and exopod 3-segmented, with posterior spinules on endo- and exopod segments 2 and 3.

P4 (Fig. 5C), coxa with medial seta, basis without seta; both endopod and exopod 3-segmented. Posterior surface of endopod segments 1,2 and 3 and exopod segments 2 and 3 with spinules.

P5 (Fig. 3E), 3-segmented, terminal segment with 3 terminal spines, central spine is longest.

DESCRIPTION. Adult male, total length $4.6 \mathrm{~mm}$; prosome 3.4 times longer than urosome. Cephalosome and pediger 1 partly fused, pedigers 4 and 5 completely fused; posterior corners of prosome extend into obtuse lobes (Fig. 6A, E). Rostrum rudimentary with a small terminal notch (Fig. 6B-C). Anal segment very small. Caudal rami with 4 terminal, 1 very small dorsolateral, and 1 ventral setae (Fig.6D-E).

Antennules (Fig. 6A, 7A-C) longer than body; right of 23 free segments, armature as follows: I-1s + 1ae, II-IV-6s + 4ae, V-2s + 2ae, VI-2s + 1ae, VII-2s + $2 \mathrm{ae}, \mathrm{VIII}-1 \mathrm{~s}+1 \mathrm{ae}, \mathrm{IX}-2 \mathrm{~s}+2 \mathrm{ae}, \mathrm{X}-\mathrm{XI}-4 \mathrm{~s}+2 \mathrm{ae}+1$ ?, XII-1?, XIII-2?, XIV-2s + 1ae, XV-2?, XVI-2s + 1ae (1 seta curved), XVII-1?, XVIII-1s + 1?, XIX-1s +1 ?, XX-2s +1 ?, XXI-1s +1 ?, XXII fused to XXIII1s, XXIV to XXVI-2s each, XXVII-XXVIII-5s + 1ae. Left of 24 free segments, armature of segments VIII - 2s + 1ae, XIII - 1?, XV - 1?, XXI - 1s, XXII $1 \mathrm{~s}, \mathrm{XXIII}-1 \mathrm{~s}$, and of remaining segments setation is the same as on the right one.

Mouthparts armament is rudimentary compared to female.

Antenna (Fig. 7D-E), coxa and basis without setae, exopod 8-segmented with $0,(0-0-0), 1,1,1,1,0$ and 3 setae; exopod nearly 0.8 times as long as endopod; first endopodal segment with 1 small seta, second with 6 and 7 setae.

Mandible (Fig. 7F, 8A), gnathobase with 9 teeth; basis with 3 setae, exopod 5-segmented, with 1, 1, 1, 1, and 2 setae; endopod segment 1 with 2 setae, segment 2 with 9 setae.

Maxillule (Fig. 7G), praecoxal arthrite with 9 terminal, 4 posterior and 1 anterior setae; coxal endite with 5 setae, proximal basal endite with 4 setae and distal basal endite with 5 setae; endopod of 3 segments 
with 3, 3, and 5 setae; exopod with 10 setae; coxal epipodite with 7 setae.

Maxilla (Fig. 8B), praecoxal endite bearing 5 setae, coxal (former considered to be distal praecoxal endite) with 3 setae; basal endites (former considered to be coxal endites): proximal with 2 sclerotized and 1 sensory setae, distal with 2 sclerotized and 1 sensory setae; lobe of proximal endopodal segment (former considered to be proximal basal endite) with 2 sclerotized and 2 sensory setae; endopod with 3 worm-like sensory, 5 brush-like sensory and 1 sclerotized setae.

Maxilliped (Fig. 8C), syncoxa with 1 worm-like sensory seta on proximal praecoxal endite, 1 sclerotized and 1 sensory setae on middle endite, and 1 worm-like and 2 sclerotized setae on distal praecoxal endite; coxal endite with 3 setae and spinules along distal edge; basis with 3 medial setae. Endopod with 2, 4, 4, 3, 3+1, and 4 setae.

P1 (Fig. 8D), coxa without seta; basis with very small distolateral seta, medial distal seta smoothly curved; endopod 1-segmented bearing lateral lobe with pore and ornamented with spinules. Exopod segments 1, 2, and 3 with 1 lateral spine each; spine of exopod segment 1 reaching to mid-length of exopod segment 2 , spine of exopod segment 2 reaching nearly to distal edge of exopod segment 3 .

P2 (Fig. 8E), coxa with medial seta; basis without seta; endopod 2-segmented; exopod 3-segmented; posterior surface of endopod segment 2 and exopod segment 2 spinulated.

P3 and P4 as in female, except lateral spines of exopod segment 1 shorter than in female.

P5 (Fig. 6F), assymetrical: right coxa plus basis slightly longer than left coxa; biramous, exopods 3segmented, endopods rudimentary; right terminal segment spine-like; left exopod segments 2 and 3 with spinules distally.

ETYMOLOGY. The name of this species honors Mark Ohman zooplanktonologist, Scripps Institution of Oceanography.

ACKNOWLEDGEMENTS. Author thanks Prof. Pedro Martinez Arbizu for providing the sorted copepod fraction of the DIVA-II expedition. The research of E.L. Markhaseva at the Deutsches Zentrum fuer Marine Biodiversitaetsforschung Senckenberg, Biozentrum Grindel and Zoologisches Museum Hamburg was supported by 12-04-00071-a grant of the Russian Foundation for Basic Research and by DFG grant RE2808/2-1.

\section{References}

Bradford-Grieve J.M. 2001. Two species of benthopelagic calanoid copepods of the genus Neoscolecithrix Canu, 1896 s.s. from New Zealand and the segregation of Cenognatha n. gen. // New Zealand Journal of Marine and Freshwater Research. Vol.35. P.781-793.

Brenke N. 2005. An epibenthic sledge for operations on marine soft bottom and bedrock // Marine Technology Society Journal. Vol.39. P.10-19.

Ferrari F.D., Markhaseva E.L. 1996. Parkius karenwishnerae, a new genus and species of calanoid copepod (Parkiidae,.new family) from benthopelagic waters of the Pacific Ocean // Proccedings of the Biological Society of Washington. Vol.109. No.2. P.264-285.

Ferrari F.D., Steinberg D. 1993. Scopalatum vorax (Esterly,1911) and Scolecithricella lobophora (Scolecitrichidae) associated with a pelagic tunicate in Monterey Bay // Proccedings of the Biological Society of Washington. Vol.106. No.3. P.467-489.

Markhaseva E.L., Ferrari F.D. 2005. New benthopelagic bradfordian calanoids Crustacea: Copepoda) from the Pacific Ocean with comments on generic Relationship // Invertebrate Zoology. Vol.2. No.2. P.111-168.

Markhaseva E.L., Schulz K. 2006. Sensiava longiseta (Copepoda, Calanoida): a new genus and species from the abyss of the Weddell Sea // Zootaxa. Vol.1368. P.1-18.

Markhaseva E.L., Schulz K. 2010. New benthopelagic calanoids (Crustacea: Copepoda) from deep Atlantic waters // Proceedings of the Zoological Institute RAS. Vol.314. No.1. P.3-23.

Ohtsuka S., Boxshall G.A., Fosshagen A. 2003. A new species of Neoscolecithrix (Crustacea; Copepoda; Calanoida) from off Okinawa, southwestern Japan, with comments on the generic position in the superfamily Clausocalanoidea // Bulletin of the National Science Museum. Ser.A. Vol.29. P.53-63.

Schulz K. 2006. New species and genus of calanoid copepods (Crustacea) from benthopelagic collections of the deep Weddell Sea, Southern Ocean // Mitteilingen aus dem Hamburgischen Zooologischen Museum und Institut. Vol.103. P.47-68.

Responsible editor V.A. Spiridonov 